\section{(- OPEN ACCESS}

\title{
Long-term exposure to air pollutants from multiple sources and mortality in an industrial area: a cohort study
}

\author{
Lisa Bauleo, ${ }^{1}$ Simone Bucci, ${ }^{1}$ Chiara Antonucci, ${ }^{1}$ Roberto Sozzi, ${ }^{2}$ Marina Davoli, ${ }^{1}$ \\ Francesco Forastiere, ${ }^{1}$ Carla Ancona $^{1}$
}

- Additional material is published online only. To view please visit the journal online (http://dx.doi.org/10.1136/ oemed-2018-105059).

${ }^{1}$ Department of Epidemiology, Lazio Regional Health Service, ASL Roma 1, Rome, Italy ${ }^{2}$ Atmosphere Division, Environmental Protection Agency, Rome, Italy

\section{Correspondence to} Lisa Bauleo, Department of Epidemiology, Lazio Regional Health Service, Rome 00147, Italy; I.bauleo@deplazio.it

Received 2 February 2018 Revised 7 August 2018 Accepted 14 August 2018 Published Online First 14 September 2018

\section{Check for updates}

(C) Author(s) (or their employer(s)) 2019. Re-use permitted under CC BY-NC. No commercial re-use. See rights and permissions. Published by BMJ.

To cite: Bauleo L,
Bucci S, Antonucci C,
et al. Occup Environ Med
2019;76:48-57.

\begin{abstract}
Background and aims Residents near industrial areas are exposed to several toxins from various sources and the assessment of the health effects is difficult. The area of Civitavecchia (Italy) has several sources of environmental contamination with potential health effects. We evaluated the association between exposure to pollutants from multiple sources and mortality in a cohort of people living in the area.

Methods All residents of the area in 1996 were enrolled (from municipal registers) and followed until 2013. Long-term exposures to emissions from industrial sources (PM10) and traffic ( $\left.\mathrm{NO}_{\mathrm{x}}\right)$ at the residential addresses were assessed using a dispersion model. Residence close to the harbour was also considered. Cox survival analysis was conducted including a linear term for industrial PM10 and $\mathrm{NO}_{\mathrm{x}}$ exposure and $\mathrm{a}$ dichotomous variable to indicate residence within 500 $\mathrm{m}$ of the harbour. Age, sex, calendar period, occupation and area-based socioeconomic position (SEP) were considered ( $\mathrm{HRs}, 95 \% \mathrm{Cl})$.

Results 71362 people were enrolled (52\% female, 43\% low SEP) and 14844 died during the follow-up. We found an association between industrial PM10 and mortality from non-accidental causes ( $H R=1.06$, $95 \% \mathrm{Cl} 1.01$ to 1.12$)$, all cancers $(\mathrm{HR}=1.11,95 \% \mathrm{Cl}$ 1.01 to 1.21$)$ and cardiac diseases $(H R=1.12,95 \% \mathrm{Cl}$ 1.01 to 1.23$)$. We also found an association between $\mathrm{NO}_{\mathrm{x}}$ exposure from traffic and mortality from all cancers $(H R=1.13,95 \% \mathrm{Cl} 1.01$ to 1.26$)$ and neurological diseases $(H R=1.50,95 \% \mathrm{Cl} 1.01$ to 2.20). Living near the harbour was associated with higher mortality from lung cancer $(H R=1.31,95 \% \mathrm{Cl} 1.04$ to 1.66$)$ and neurological diseases ( $H R=1.51,95 \% \mathrm{Cl} 1.05$ to 2.18). Conclusions Estimated exposures to different pollution sources in this area were independently associated with several mortality outcomes while adjusting for occupation and socioeconomic status.
\end{abstract}

\section{INTRODUCTION}

Residents of the area of Civitavecchia (northern coast of Rome, Lazio region) have been exposed to various sources of environmental contamination, including a large industrial site (a cement factory, and three thermoelectric power plants), vehicular traffic (with diesel truck traffic) and a large harbour. Previous studies carried out in this area have shown high risks for respiratory diseases and lung cancer both among workers ${ }^{1-4}$ and residents. ${ }^{5-7}$

\section{Key messages}

What is already known about this subject?

- Previous epidemiological study carried out in the industrial area of Civitavecchia indicated increased mortality and morbidity among workers and residents (including children).

- However, data about individual exposure to pollutants from the different sources were not available.

What are the new findings?

- The baseline address of residence for each subject was geocoded and it was possible to assess the individual exposure to the different pollutant sources.

- Dispersion models were used to estimate individual exposure and the confounding effect of occupational exposure and socioeconomic status was taken into account.

- We found an association between industrial PM10 and mortality from non-accidental and cardiac causes.

- In addition, there was a link with pancreatic, pleural and kidney cancer.

- Neurological diseases mortality was associated with road traffic estimated with $\mathrm{NO}_{\mathrm{x}}$ and harbour proximity.

- People living close to the harbour showed increased risk for lung cancer mortality.

\section{How might this impact on policy or clinical practice in the foreseeable future? \\ - The results indicate the need to limit industrial (PM10) and road traffic (NO) emissions to protect the health of the local population.}

Recent investigations ${ }^{8-10}$ have used dispersion models to assess population exposure, an approach that provides a better assessment than studies based on simply the distance from the source, especially when used in combination with a residential cohort study. ${ }^{11}$

We aimed to evaluate the long-term effects on mortality of exposures to industrial sources, urban traffic and vicinity to the harbour in a cohort of people living in the area of Civitavecchia. Dispersion models were used to assess exposure and the 
confounding effects of occupational exposure and socioeconomic status were considered.

\section{METHODS}

\section{Air pollution sources}

Three thermoelectric power plants were located in the study area: Fiumaretta, Tor Valdaliga South (TVS) and Tor Valdaliga North (TVN). The Fiumaretta power plant, which closed in 1990, was located very close to the Civitavecchia city centre. It began operating in 1953 as a coal-fired plant producing $70 \mathrm{MW}$ of power; later the fuel was changed to oil and in 1969 the power was increased to $460 \mathrm{MW}$. The TVS power plant is located about $4 \mathrm{~km}$ of the town centre. It has been active since 1964 as an oil-fuelled plant producing $1140 \mathrm{MW}$ of power; it was recently converted to a gas-fuelled plant. The TVN power plant is located about $5 \mathrm{~km}$ of the town centre, near the TVS; it has been active since 1984 producing $2640 \mathrm{MW}$ of power; it was converted to a coal-fired power plant in 2010. Emissions from the power plants include particulate matter $(\mathrm{PM})$, nitrogen oxides $\left(\mathrm{NO}_{\mathrm{x}}\right)$ and sulfur dioxide $\left(\mathrm{SO}_{2}\right)$.

A cement factory $\left(6500 \mathrm{~m}^{2}\right)$ was active from the turn of the century until the $90 \mathrm{~s}$ in the town of Civitavecchia. $\mathrm{SO}_{2}, \mathrm{NO}_{\mathrm{x}}$ and total suspended particle levels showed high values in the 1980s, but they started to decrease during the early 1990s.

All the plants under study identified by their chimney coordinates were geocoded using the World Geodetic System of 1984 with the Universal Transverse Mercator zone 33 Nord projection (WGS84_UTM33N).

The Civitavecchia harbour $\left(241000 \mathrm{~m}^{2}, 26\right.$ operational piers, 23 berths for up to $100 \mathrm{~m}$ yachts) has been traditionally used for ferry traffic, merchant ships and tankers. The improvement of docks and structures for passengers over the years allowed for an extraordinary increase of cruise ships (from 50 ships in 1996 to 950 in 2013) and ferries (1500 yearly) with an annual average number of passengers reaching up to 4 million in recent years. Environmental surveys indicate that dusty material (around 500000 tons/year) is the main source of pollution from the harbour, causing increased dust dispersion in the air when the goods are transferred from container to trucks. Another source of pollution from the harbour is the traffic from industrial vehicles and ferries: ships and ferries use a large amount of fuel containing high sulfur levels (up to 2.9\%), and produce substantial quantities of sulfur oxides and particulates.

In addition to the pollution produced by the industrial plants and the harbour, air quality in the area has been affected by traffic, mostly diesel vehicles. In 2012, a total of 84000 vehicles per day (65000 cars, 6000 trucks, 13000 motorcycles) were estimated in the area with a large component of vehicles in transit due to the harbour, especially during the summer.

\section{Exposure assessment}

We used a Lagrangian particle dispersion model called SPRAY (www.aria-net.it) to simulate the spatial concentration of PM10 as a surrogate measure of contaminants emitted by the industrial plants. The SPRAY model simulates the transport, dispersion and deposition of pollutants using orography, meteorological data, turbulence and hourly spatial distribution. A PM10 concentration value was estimated for each of the four industrial sources (three power plants and the cement factory) using emission parameters from $1988 .{ }^{12}$ Annual average emissions were estimated for each $500 \times 500 \mathrm{~m}$ cell in a domain of $50 \times 50 \mathrm{~km}^{2}$.

We did not have historical information about airborne emissions from harbour activities. Therefore, the linear distance between the subject address and the perimeter of the harbour was considered as proxy of the exposure to harbour pollution. We considered all residents exposed who lived in the $500 \mathrm{~m}$ buffer from the harbour.

Outdoor concentrations of $\mathrm{NO}_{x}$ at the residential address of the cohort participants were estimated as tracers of urban traffic pollution. Data for dispersion model simulations were estimated from two road traffic measurement campaigns (winter and summer 2014) made in a sample of major traffic roads selected from the Functional Road Class attribute $(\mathrm{FRC}=1-5$ ) (included in the Tele Atlas MultiNet road network). The sampling points were chosen according to the population density in the area. The number of heavy and light vehicles in transit in 15 min periods on each road was collected to estimate the annual flow by category (light and heavy). This number was multiplied by the length of the road (in $\mathrm{km}$ ) and the emission factor, which depends on the pollutant and the type of vehicle. Measurement campaigns were not available for the highway $(\mathrm{FRC}=0)$ and the annual traffic flow by category was estimated considering weekly data available from the National Autonomous Roads. The results of the simulations carried out for light and heavy traffic were then added to estimate the total concentrations. Annual average emissions were estimated for each $500 \times 500 \mathrm{~m}$ cell in a domain of $50 \times 50 \mathrm{~km}^{2}$.

Emission data of industrial and traffic pollution from PM2.5 were not available.

\section{Enrolment of the cohort and health outcomes}

All residents (18+ years) living in the area on 1 January 1996 were enrolled in the cohort. For each subject, personal data, baseline address of residence geocoded using the ArcGIS software address, date of immigration (and eventual emigration) and vital status were available. The follow-up for vital status was carried out through the municipal registry and record linkage with the regional mortality database, which includes all deaths of the resident population. Vital status for people who moved outside the study area in the period 1996-2013 was recorded via linkage with the Regional Health Management file. Subjects were considered at risk until they died, moved outside the Lazio region, or until the last day of the follow-up (31 December 2013).

We analysed non-accidental and cause-specific mortality. We considered causes of death for which there was some plausible association with environmental and occupational factors (ICD-9 codes in online supplementary appendix 1) and we did not consider accidental mortality. Each subject in the cohort was assigned a baseline value of pollutant exposure corresponding to the estimated map values of their residence.

\section{Occupations and other confounders}

Each cohort participant was linked to the National Pension Fund database, which includes information on individual jobs with private employment companies since 1974 . We identified ever employment in the service industry, construction industry, construction product (cement factory), agriculture, mechanical constructions, iron and steel industry, naval construction, dock worker, transportation, gas and electric industries and manufacture of refined petroleum products based on the mandatory contribution paid for at least 1 year before enrolment.

We considered age, sex, birthplace (North, Centre, Lazio region, South Italy, outside Italy) and a socioeconomic position (SEP) index (high, medium, low). SEP is a small area index based on the census block (around 500 inhabitants) and defined based on information recorded at the 2001 census. $^{13}$ 


\section{Statistical analysis and measures of association}

We measured person-time at risk for cohort participants from the beginning of follow-up (1 January 1996) to the end of follow-up (31 December 2013), or to the date of emigration, or death. Person-time was calculated separately by sex, age and calendar period. We used gender-specific Cox proportional hazard regression models (HRs and 95\% CI) to study the association between air pollution and the study outcomes, with age as the underlying time variable. To consider possible time-related changes in mortality rates during the study period, the analyses were performed stratifying by calendar period (1996-2001; 2002-2007; 2008-2013).

Exposures to PM10 from industrial sources and to $\mathrm{NO}_{\mathrm{x}}$ from traffic were modelled as a fixed continuous variable using the annual mean exposure at residence. Because of the varying magnitude of the exposure indicator, a linear association was estimated for an increment equal to the difference between the 95 th and the 5 th percentiles of the distribution of each pollutant. A dichotomous variable was used to indicate residence within $500 \mathrm{~m}$ of the harbour.

Potential confounders considered were region of birth, SEP, occupational exposure and other environmental exposures besides that under study. In order to disentangle the role of each exposure, we performed single and multivariate model for the environmental exposures. Furthermore, we explored the form of the exposure-response relationship between environmental exposures and outcomes by using a semiparametric smoothed curve, the natural spline. ${ }^{14}$

We performed a model for each occupational category for male employees. We estimated HRs and included in the models the environmental exposures under study, birthplace, SEP, bluecollar (yes or no), and a four-level variable was considered: private sector employment (in any of the following: construction industry, cement factory, agriculture, mechanical construction, iron and steel industry, naval construction, dock worker, transportation, gas and power industries and manufacture of refined petroleum products), workers in private service industry (including commerce), workers in other private sectors and no private workers (people for whom it was not possible to find pension contributions from the private sector). Workers in private service industry (including commerce) were considered as reference category.

SAS version 9.2 (SAS Institute) and STATA vers.12 (StataCorp, Texas) software programs were used for the statistical analyses.

\section{RESULTS}

Figure 1 illustrates the study area (A) and air pollution from different sources: PM10 industrial concentration (B), urban traffic $\mathrm{NO}_{\mathrm{x}}(\mathrm{C})$ and the harbour with the $500 \mathrm{~m}$ buffer (D).

A total of 71362 individuals were enrolled in the cohort in 1996 (52.3\% female) and baseline concentrations of PM10 from industrial sources and $\mathrm{NO}_{\mathrm{x}}$ from traffic were estimated for each of them at their residential address. We considered total industrial PM10 concentration because of the proximity to the thermoelectric plants and cement plant and the high correlations among pollutant concentrations estimated from the single sources (online supplementary figure S1). Annual average exposure levels of the population (mean (SD, 50th percentile, 95th5 th percentile)) to PM10 of industrial origin were $4.49 \mu \mathrm{g} / \mathrm{m}^{3}$ $(1.97,4.27,5.49)$, and $5.80 \mu \mathrm{g} / \mathrm{m}^{3}(3.86,5.17,12.77)$ for $\mathrm{NO}_{\mathrm{x}}$. Few subjects $(6.5 \%)$ lived within $500 \mathrm{~m}$ of the harbour.

The main characteristics of the subjects according to exposure to PM10 from industrial sources, to $\mathrm{NO}_{\mathrm{x}}$ from traffic (divided
A

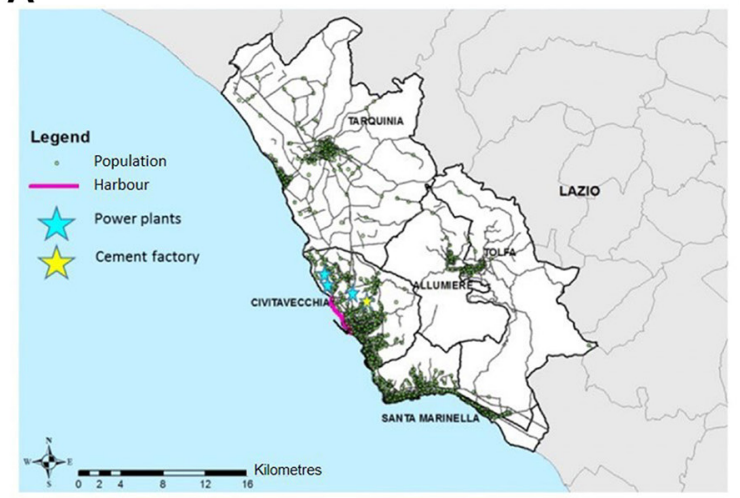

C

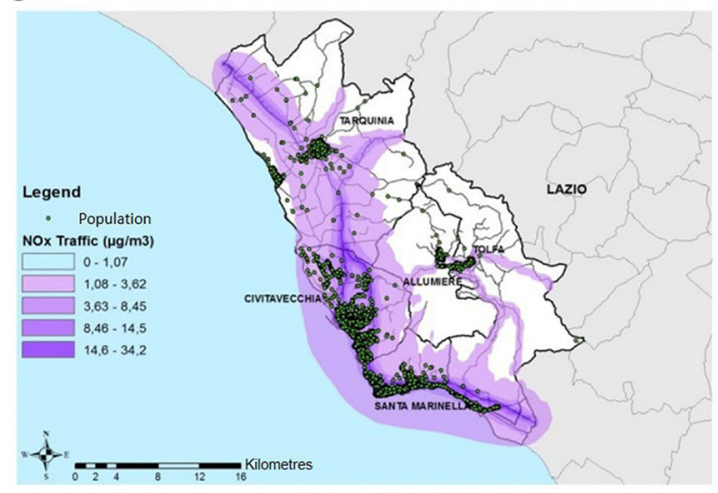

B

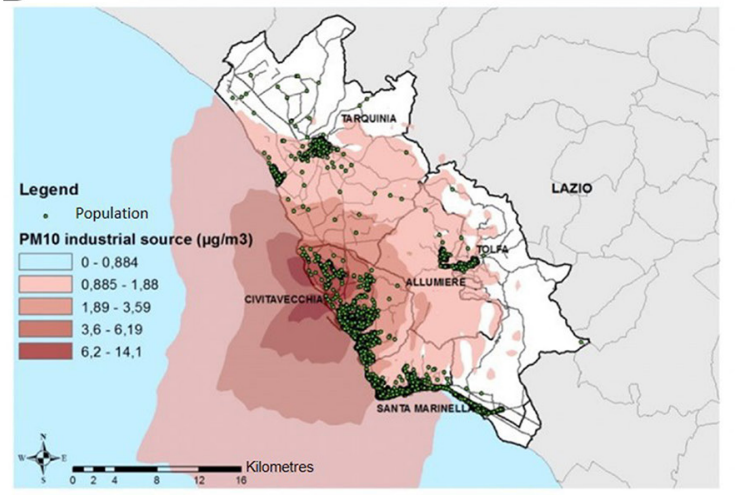

D

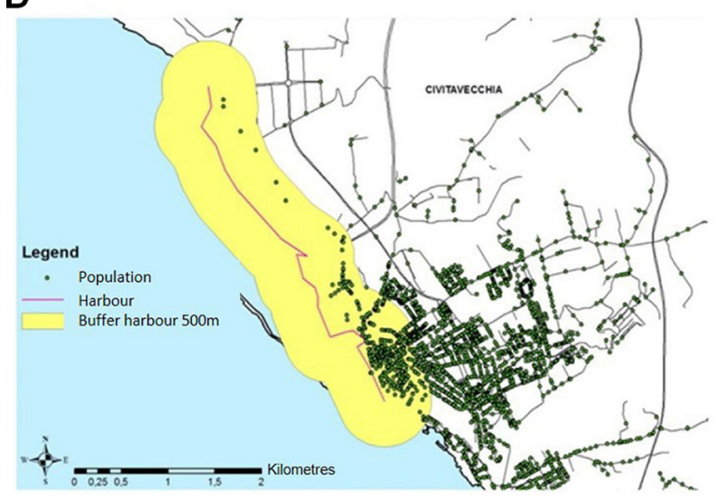


Table 1 Descriptive individual and environmental characteristics of the cohort members

\begin{tabular}{|c|c|c|c|c|c|c|c|c|c|c|}
\hline \multirow[b]{3}{*}{ Total cohort } & \multirow[b]{3}{*}{71362} & & \multicolumn{3}{|c|}{ PM10 from industrial sources } & \multicolumn{3}{|c|}{$\mathrm{NO}_{\mathrm{x}}$ from traffic } & \multicolumn{2}{|c|}{$\begin{array}{l}\text { Distance from the } \\
\text { harbour }\end{array}$} \\
\hline & & & $<5$ th & $5^{\circ}-95^{\circ}$ & $>95$ th & $<5$ th & $5^{\circ}-95^{\circ}$ & $>95$ th & $>500 \mathrm{~m}$ & $\leq 500 \mathrm{~m}$ \\
\hline & & & 3639 & 64540 & 3183 & 3488 & 64371 & 3503 & 66698 & 4664 \\
\hline \multicolumn{11}{|l|}{ Sex } \\
\hline Male & 34016 & 47.7 & 48.0 & 47.4 & 51.7 & 50.1 & 47.4 & 50.0 & 47.7 & 46.9 \\
\hline Female & 37346 & 52.3 & 52.0 & 52.6 & 48.3 & 49.9 & 52.6 & 50.0 & 52.3 & 53.1 \\
\hline \multicolumn{11}{|l|}{ Age class (years) } \\
\hline $18-44$ & 35466 & 49.7 & 46.7 & 49.3 & 61.3 & 52.6 & 48.6 & 67.1 & 50.0 & 45.9 \\
\hline $45-64$ & 21690 & 30.4 & 31.0 & 30.6 & 25.7 & 29.0 & 30.9 & 23.2 & 30.5 & 28.9 \\
\hline $65-80$ & 11502 & 16.1 & 17.9 & 16.3 & 10.6 & 14.5 & 16.6 & 8.5 & 15.9 & 19.8 \\
\hline$>80$ & 2704 & 3.8 & 4.5 & 3.8 & 2.5 & 3.9 & 3.9 & 1.3 & 3.7 & 5.3 \\
\hline \multicolumn{11}{|l|}{ Region of birth } \\
\hline Lazio & 51813 & 72.6 & 73.5 & 72.6 & 70.7 & 81.3 & 72.1 & 72.5 & 72.9 & 68.6 \\
\hline North & 2340 & 3.3 & 3.8 & 3.3 & 3.1 & 2.8 & 3.3 & 2.6 & 3.3 & 3.4 \\
\hline Centre (except Lazio) & 3572 & 5.0 & 7.7 & 4.8 & 5.8 & 4.8 & 5.1 & 4.2 & 5.1 & 4.1 \\
\hline South & 11531 & 16.2 & 10.7 & 16.4 & 17.9 & 8.6 & 16.5 & 18.1 & 15.8 & 21.2 \\
\hline Other nation & 2106 & 3.0 & 4.2 & 2.9 & 2.5 & 2.6 & 3.0 & 2.5 & 3.0 & 2.7 \\
\hline \multicolumn{11}{|l|}{ Socioeconomic position ${ }^{*}$} \\
\hline High & 9592 & 15.2 & 18.4 & 15.8 & 0.4 & 13.8 & 15.2 & 13.5 & 13.9 & 9.6 \\
\hline Middle-high & 10078 & 16.0 & 28.0 & 15.4 & 14.6 & 32.3 & 15.9 & 0.8 & 14.1 & 19.9 \\
\hline Middle & 13360 & 21.2 & 27.8 & 21.0 & 19.3 & 21.7 & 21.9 & 5.2 & 19.8 & 5.2 \\
\hline Middle-low & 13247 & 21.0 & 20.9 & 21.0 & 20.9 & 21.4 & 21.0 & 17.4 & 19.1 & 14.3 \\
\hline Low & 16697 & 26.5 & 5.0 & 26.7 & 44.7 & 10.8 & 25.9 & 45.3 & 22.5 & 51.0 \\
\hline \multicolumn{11}{|l|}{ Occupational categories } \\
\hline Ever worked & 28346 & 39.7 & 45.3 & 39.2 & 44.1 & 45.7 & 39.2 & 42.8 & 40.3 & 31.3 \\
\hline Services industry & 12934 & 18.1 & 17.4 & 18.2 & 17.8 & 15.3 & 18.2 & 18.8 & 18.2 & 16.8 \\
\hline Construction industry & 5073 & 7.1 & 7.5 & 7.0 & 7.9 & 10.0 & 6.8 & 9.3 & 7.3 & 4.4 \\
\hline Construction products (cement factory) & 485 & 0.7 & 0.7 & 0.6 & 1.6 & 0.7 & 0.7 & 0.8 & 0.7 & 0.7 \\
\hline Agriculture & 4881 & 6.8 & 18.0 & 6.2 & 8.0 & 16.7 & 6.4 & 6.0 & 7.2 & 1.7 \\
\hline Mechanical constructions & 2491 & 3.5 & 2.7 & 3.5 & 4.8 & 3.9 & 3.5 & 3.8 & 3.5 & 2.8 \\
\hline Iron and steel industry & 588 & 0.8 & 0.2 & 0.8 & 1.7 & 0.4 & 0.8 & 1.3 & 0.8 & 0.9 \\
\hline Naval constructions & 124 & 0.2 & 0.0 & 0.2 & 0.2 & 0.1 & 0.2 & 0.2 & 0.2 & 0.3 \\
\hline Dock worker & 1580 & 2.2 & 0.1 & 2.3 & 3.3 & 0.4 & 2.3 & 2.7 & 2.2 & 3.1 \\
\hline Transports & 1121 & 1.6 & 1.3 & 1.6 & 1.7 & 1.1 & 1.6 & 1.4 & 1.6 & 1.4 \\
\hline Gas and power industries & 1678 & 2.4 & 0.6 & 2.4 & 4.1 & 1.7 & 2.4 & 2.3 & 2.4 & 1.9 \\
\hline $\begin{array}{l}\text { Manufacture of refined petroleum } \\
\text { products }\end{array}$ & 159 & 0.2 & 0.1 & 0.2 & 0.3 & 0.1 & 0.2 & 0.3 & 0.2 & 0.2 \\
\hline Other & 2225 & 3.1 & 3.1 & 3.1 & 3.1 & 3.3 & 3.1 & 3.8 & 3.1 & 2.7 \\
\hline \multicolumn{11}{|l|}{ Vital status (on 31 December 2013) } \\
\hline Alive & 53408 & 74.8 & 72.6 & 74.7 & 79.5 & 76.4 & 74.1 & 86.2 & 75.3 & 67.9 \\
\hline Emigrated or untraceable & 3110 & 4.4 & 4.8 & 4.3 & 5.2 & 4.4 & 4.5 & 2.0 & 4.2 & 6.0 \\
\hline Dead & 14844 & 20.8 & 22.6 & 21.0 & 15.4 & 19.2 & 21.4 & 11.7 & 20.4 & 26.1 \\
\hline \multicolumn{11}{|l|}{ Person-years } \\
\hline 1996-2001 & 71357 & 36.4 & 36.6 & 36.4 & 35.8 & 36.3 & 36.4 & 34.8 & 36.3 & 37.4 \\
\hline 2002-2007 & 65327 & 33.3 & 33.4 & 33.3 & 33.2 & 33.2 & 33.3 & 33.4 & 33.3 & 33.2 \\
\hline 2008-2013 & 59622 & 30.4 & 30.0 & 30.4 & 31.0 & 30.5 & 30.3 & 31.9 & 30.4 & 29.5 \\
\hline
\end{tabular}

*Total may vary because of missing values.

by $<5$ th, 5 th- 95 th, $>95$ th percentile cut-offs) and distance from the harbour $(\leq 500 \mathrm{~m},>500 \mathrm{~m})$ are described in table 1 . Sex distribution was rather similar over the environmental exposure categories. However, people living in areas with higher concentrations of PM10 or NO were more likely to be younger and have a lower SEP compared with people living in areas with lower concentrations of pollutants. People who lived closer to the harbour were more likely to have been born in South Italy and to be of lower SEP compared with those who lived far away. Almost 40\% of the people in the cohort (18299 men and 10047 women) had pension contributions for at least 1 year before enrolment. The prevalent occupational category was the service industry (12 934) while 5073 people were employed in the construction industry and 4881 in agriculture. People living in areas with lower concentrations of pollutants were more likely to work in agriculture. During the study period, we observed 14844 deaths for non-accidental causes $(32.3 \%$ from cancer, $39.1 \%$ from cardiovascular diseases and $6.4 \%$ from respiratory diseases), while 3110 subjects moved away from the Lazio region. 
Table 2 Association between PM10 (industrial), NOx (traffic) and distance from the harbour exposure and cause-specific mortality. Adjusted HRs and $95 \% \mathrm{Cl}$ per a linear increase equal to the difference between the 95 th and 5 th percentiles of each pollutant (5.49 and 12.77, respectively)

\begin{tabular}{|c|c|c|c|c|c|c|c|}
\hline \multirow[b]{2}{*}{ Causes of death (ICD-9 codes) } & \multirow[b]{2}{*}{$\mathrm{n}$} & \multicolumn{2}{|c|}{ PM10 from industrial sources } & \multicolumn{2}{|c|}{$\mathrm{NO}_{\mathrm{x}}$ from traffic } & \multicolumn{2}{|c|}{ Distance from the harbou } \\
\hline & & HR adj & $95 \% \mathrm{Cl}$ & HR adj & $95 \% \mathrm{Cl}$ & HR adj & $95 \% \mathrm{Cl}$ \\
\hline Non-accidental causes (001-799) & 13687 & 1.06 & 1.01 to 1.12 & 0.98 & 0.91 to 1.05 & 1.03 & 0.96 to 1.10 \\
\hline Stomach (151) & 294 & 0.87 & 0.61 to 1.25 & 1.05 & 0.68 to 1.63 & 1.39 & 0.89 to 2.17 \\
\hline Colon and rectum $(153-154 ; 159)$ & 585 & 1.05 & 0.82 to 1.35 & 1.14 & 0.83 to 1.57 & 1.09 & 0.79 to 1.50 \\
\hline Liver (155-156) & 291 & 1.33 & 0.94 to 1.86 & 1.22 & 0.79 to 1.88 & 0.99 & 0.63 to 1.54 \\
\hline Trachea, bronchus and lung (162) & 1046 & 1.10 & 0.92 to 1.33 & 1.19 & 0.95 to 1.49 & 1.31 & 1.04 to 1.66 \\
\hline Pleura (163) & 29 & 3.75 & 1.46 to 9.64 & 2.53 & 0.82 to 7.75 & 0.61 & 0.14 to 2.63 \\
\hline Bladder (188) & 181 & 1.03 & 0.65 to 1.61 & 0.72 & 0.38 to 1.38 & 1.11 & 0.62 to 1.98 \\
\hline Kidney (189) & 103 & 1.79 & 1.05 to 3.06 & 1.83 & 0.96 to 3.52 & 0.29 & 0.09 to 0.95 \\
\hline Brain and other parts of CNS $(191-192 ; 225)$ & 92 & 0.96 & 0.51 to 1.81 & 1.31 & 0.67 to 2.59 & 0.84 & 0.35 to 2.02 \\
\hline Ischaemic heart diseases (410-414) & 1623 & 1.14 & 0.98 to 1.33 & 0.83 & 0.67 to 1.01 & 1.10 & 0.91 to 1.32 \\
\hline Acute coronary events (410-411) & 847 & 1.06 & 0.86 to 1.31 & 0.82 & 0.62 to 1.08 & 1.20 & 0.94 to 1.54 \\
\hline Cerebrovascular diseases (430-438) & 1324 & 1.04 & 0.88 to 1.23 & 0.78 & 0.61 to 0.99 & 0.86 & 0.69 to 1.08 \\
\hline Respiratory diseases (460-519) & 874 & 1.10 & 0.90 to 1.34 & 1.14 & 0.87 to 1.49 & 0.79 & 0.60 to 1.04 \\
\hline COPD $(490-492,494,496)$ & 358 & 0.98 & 0.72 to 1.35 & 1.34 & 0.90 to 1.99 & 0.93 & 0.61 to 1.41 \\
\hline Digestive system diseases (520-579) & 561 & 1.22 & 0.95 to 1.56 & 0.81 & 0.57 to 1.15 & 1.04 & 0.75 to 1.43 \\
\hline Renal diseases (580-599) & 242 & 1.17 & 0.80 to 1.73 & 0.85 & 0.49 to 1.48 & 0.91 & 0.56 to 1.50 \\
\hline
\end{tabular}

CNS, central nervous system; COPD, chronic obstructive pulmonary disease; ICD-9, International Classification of Diseases, Ninth Revision.

We found higher risks of non-accidental mortality $(\mathrm{HR}=1.06$, 95\% CI 1.01 to 1.12 ), all malignant cancers ( $\mathrm{HR}=1.11,95 \% \mathrm{CI}$ 1.01 to 1.21$)$ and cardiac diseases ( $\mathrm{HR}=1.12,95 \% \mathrm{CI} 1.01$ to 1.23) for increment of industrial PM10 equal to the difference between the 95 th and 5 th percentiles $\left(5.49 \mu \mathrm{g} / \mathrm{m}^{3}\right)$. The specific cancer types for which mortality was higher were pancreatic $(\mathrm{HR}=1.49,95 \% \mathrm{CI} 1.02$ to 2.16$)$, pleural $(\mathrm{HR}=3.75,95 \% \mathrm{CI}$ 1.46 to 9.64 ) and kidney (HR=1.79, 95\% CI 1.05 to 3.06 ). Industrial PM10 was weakly associated with lymphatic cancer $(\mathrm{HR}=1.28,95 \% \mathrm{CI} 0.95$ to 1.74$)$, ischaemic heart diseases $(\mathrm{HR}=1.14,95 \% \mathrm{CI} 0.98$ to 1.33$)$ and digestive system diseases $(\mathrm{HR}=1.22,95 \% \mathrm{CI} 0.95$ to 1.56$)$. We also found an association between $\mathrm{NO}$ concentrations and malignant cancers $(\mathrm{HR}=1.13,95 \% \mathrm{CI} 1.01$ to 1.26$)$, lung ( $\mathrm{HR}=1.19,95 \% \mathrm{CI}$ 096 to 1.49$)$ and kidney cancers $(\mathrm{HR}=1.83,95 \% \mathrm{CI} 0.96$ to $3.52)$ and neurological diseases $(\mathrm{HR}=1.50,95 \% \mathrm{CI} 1.01$ to 2.20). Residing near the harbour was associated with mortality from all cancers ( $\mathrm{HR}=1.11,95 \% \mathrm{CI} 0.99$ to 1.25$)$, lung cancer $(\mathrm{HR}=1.31,95 \% \mathrm{CI} 1.04$ to 1.66$)$ and neurological diseases ( $\mathrm{HR}=1.51,95 \% \mathrm{CI} 1.05$ to 2.18 ) (table 2). A supplementary analysis performed after stratification for sex (online supplementary tables S1 and S2) confirmed these results. Figure 2 shows the concentration-response curves for non-accidental, cancer and cardiac disease mortality related to industrial PM10. For all three outcomes, we observed relationships that were almost linear with slopes that were steeper at the beginning and then flatter in the middle and final parts (with large CIs).

Table 3 reports the results of the association between occupational categories of exposure and cause-specific mortality among men. We found higher risk for non-accidental mortality for men employed in the construction industry ( $\mathrm{HR}=1.14,95 \% \mathrm{CI} 1.04$ to 1.25$)$ and among agriculture workers ( $\mathrm{HR}=1.20,95 \% \mathrm{CI} 1.07$ to 1.34 ) while comparing with workers in private service industry. We also found increased risk of all malignant cancers $(\mathrm{HR}=1.16$, 95\% CI 1.01 to 1.34 ), lung cancer ( $\mathrm{HR}=1.41,95 \% \mathrm{CI} 1.11$ to 1.81 ) and respiratory disease mortality ( $\mathrm{HR}=1.47,95 \% \mathrm{CI} 1.01$ to 2.14) among construction workers, of kidney cancer ( $\mathrm{HR}=3.74$, $95 \%$ CI 1.26 to 11.08 ) among construction product workers, of cardiovascular ( $\mathrm{HR}=1.24,95 \% \mathrm{CI} 1.03$ to 1.51$)$, respiratory $(\mathrm{HR}=1.61,95 \% \mathrm{CI} 1.00$ to 2.59$)$ and digestive disease mortality $(\mathrm{HR}=2.13$, 95\% CI 1.19 to 3.81) among male agriculture workers, of larynx cancer (HR=2.13, 95\% CI 1.19 to 3.81) in dock workers and of lymphatic cancer $(\mathrm{HR}=2.24,95 \% \mathrm{CI} 1.12$ to 4.46$)$ and neurological disease mortality $(\mathrm{HR}=2.13,95 \% \mathrm{CI}$ 1.19 to 3.81 ) in male transportation workers while comparing with workers in private service industry.

In order to disentangle the roles of SEP, occupational and environmental exposures, we performed a sensitivity analysis in four steps for each environmental exposure (industries, distance from harbour and urban traffic). Methodology and results (online supplementary tables S3-S5) are reported in online supplementary appendix 2 .

\section{DISCUSSION}

We found a relationship between industrial PM10 and mortality from non-accidental, cancer and cardiac causes. In addition, there was a link with pancreatic, pleural and kidney cancer. Cardiac mortality was associated with traffic pollution. Neurological disease mortality was associated with traffic $\mathrm{NO}_{x}$ and harbour proximity. Finally, people living close to the harbour showed a higher risk of lung cancer mortality. These results were adjusted for the concomitant environmental exposures, SEP and occupational exposure. 
A

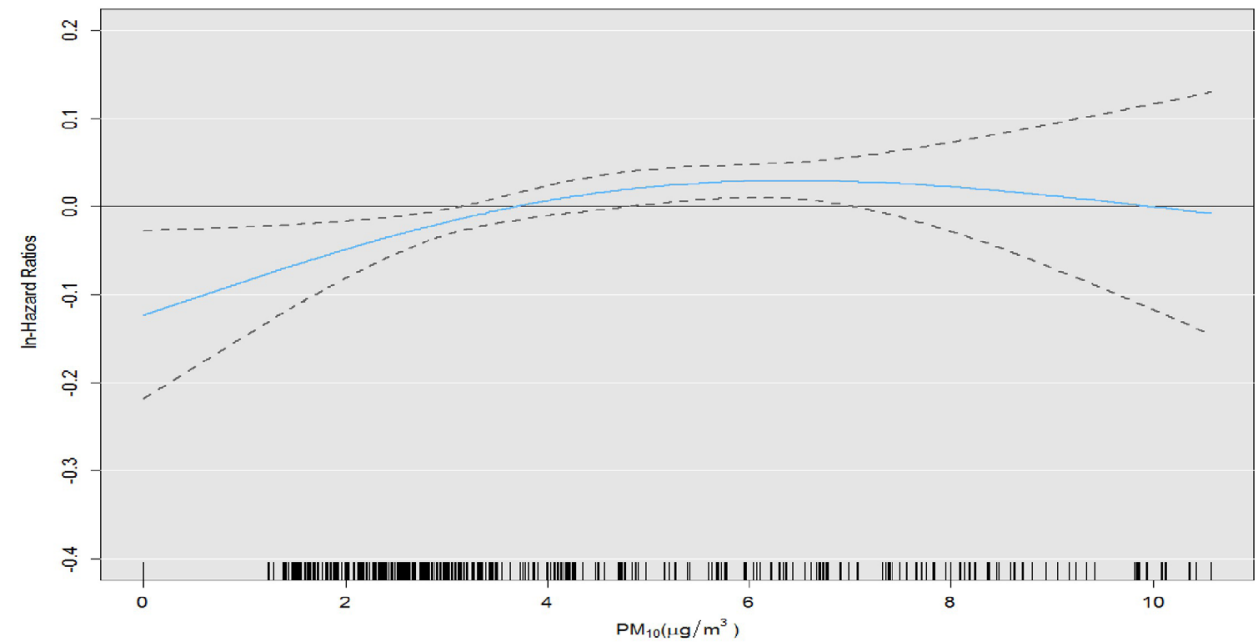

B

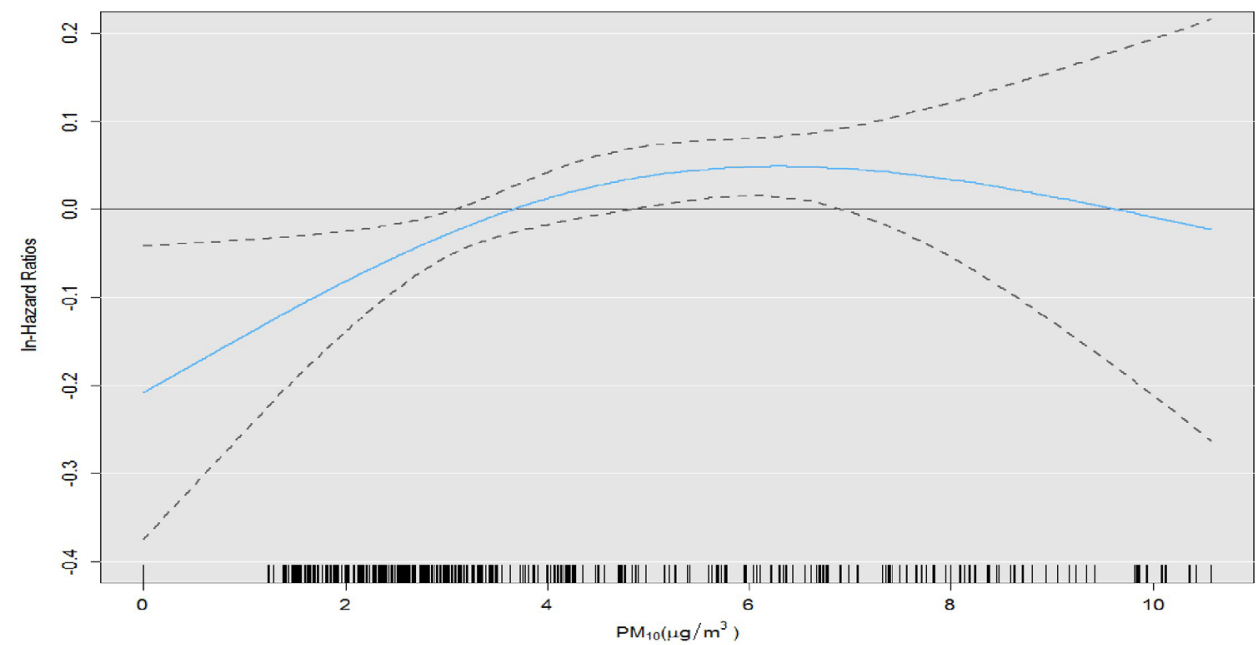

C

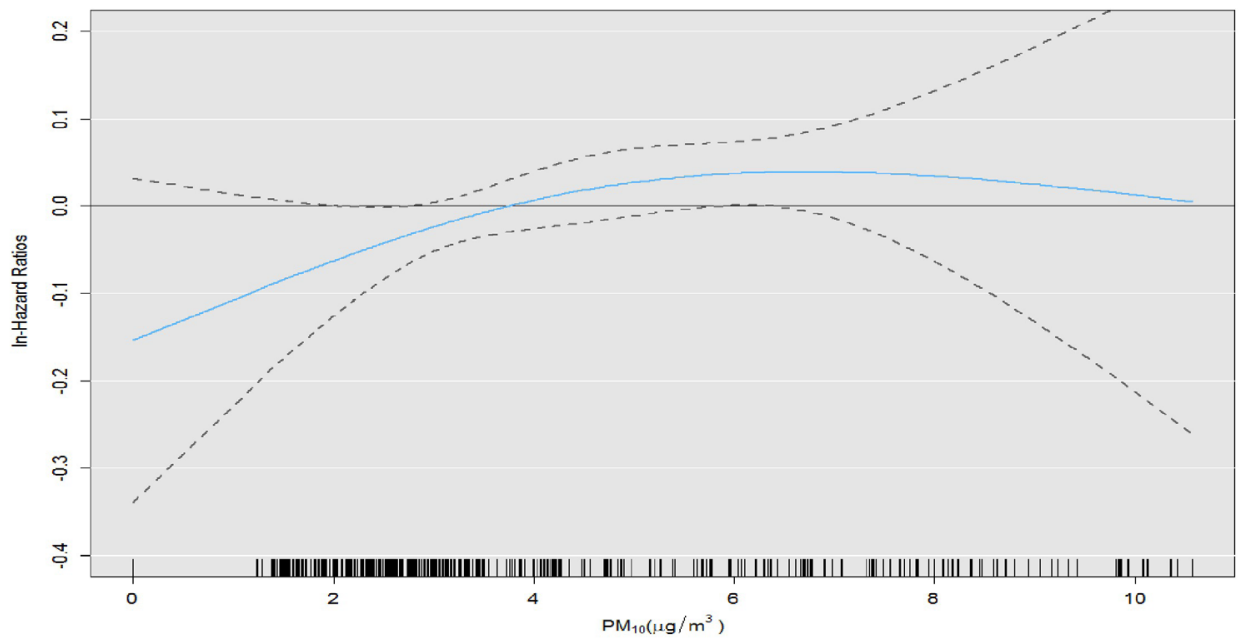

Figure 2 Concentration-response curves of industrial PM10 and mortality ( $A$, non-accidental; B, cancer; C, cardiac disease). X-axis is average PM10 exposure $\left(\mu \mathrm{g} / \mathrm{m}^{3}\right)$. The black line is the mean estimate and the dotted lines are its $95 \% \mathrm{Cls}$. 
Table 3 Association between occupational categories of exposure and cause-specific mortality in men. Adjusted $\mathrm{HRs}$ and $95 \% \mathrm{Cl}$

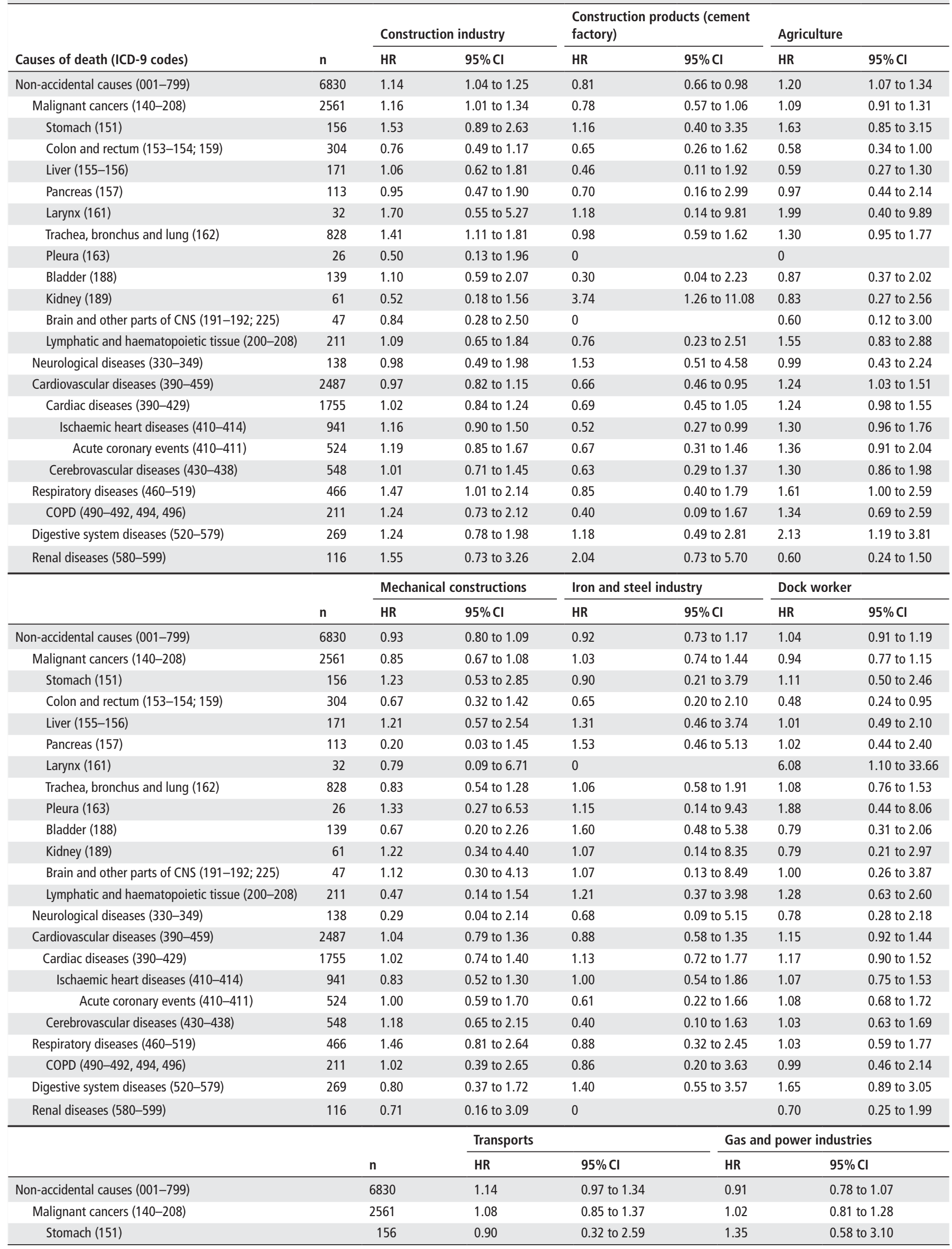


Table 3 continued

\begin{tabular}{|c|c|c|c|c|c|}
\hline & \multirow[b]{2}{*}{$\mathrm{n}$} & \multicolumn{2}{|c|}{ Transports } & \multicolumn{2}{|c|}{ Gas and power industries } \\
\hline & & HR & $95 \% \mathrm{Cl}$ & HR & $95 \% \mathrm{Cl}$ \\
\hline Colon and rectum $(153-154 ; 159)$ & 304 & 1.08 & 0.55 to 2.11 & 1.06 & 0.57 to 1.97 \\
\hline Liver (155-156) & 171 & 1.46 & 0.67 to 3.15 & 1.15 & 0.53 to 2.49 \\
\hline Pancreas (157) & 113 & 0.23 & 0.03 to 1.73 & 1.79 & 0.83 to 3.83 \\
\hline Larynx (161) & 32 & 0 & & 0 & \\
\hline Trachea, bronchus and lung (162) & 828 & 1.04 & 0.68 to 1.59 & 1.00 & 0.66 to 1.51 \\
\hline Pleura (163) & 26 & 0 & & 2.87 & 0.85 to 9.70 \\
\hline Bladder (188) & 139 & 0.55 & 0.13 to 2.33 & 0.98 & 0.34 to 2.86 \\
\hline Kidney (189) & 61 & 1.54 & 0.43 to 5.48 & 0.42 & 0.05 to 3.25 \\
\hline Brain and other parts of CNS $(191-192 ; 225)$ & 47 & 0 & & 0.46 & 0.06 to 3.58 \\
\hline Lymphatic and haematopoietic tissue (200-208) & 211 & 2.24 & 1.12 to 4.46 & 0.83 & 0.32 to 2.13 \\
\hline Neurological diseases (330-349) & 138 & 2.71 & 1.13 to 6.51 & 0.52 & 0.12 to 2.23 \\
\hline Cardiovascular diseases (390-459) & 2487 & 1.30 & 0.99 to 1.70 & 0.84 & 0.63 to 1.11 \\
\hline Cardiac diseases (390-429) & 1755 & 1.23 & 0.88 to 1.70 & 0.85 & 0.61 to 1.19 \\
\hline Ischaemic heart diseases (410-414) & 941 & 1.16 & 0.75 to 1.81 & 0.87 & 0.57 to 1.35 \\
\hline Acute coronary events (410-411) & 524 & 1.42 & 0.84 to 2.40 & 0.90 & 0.52 to 1.57 \\
\hline Cerebrovascular diseases (430-438) & 548 & 1.40 & 0.79 to 2.48 & 1.05 & 0.59 to 1.86 \\
\hline Respiratory diseases (460-519) & 466 & 1.27 & 0.64 to 2.49 & 0.90 & 0.44 to 1.81 \\
\hline COPD $(490-492,494,496)$ & 211 & 1.54 & 0.64 to 3.74 & 1.51 & 0.69 to 3.30 \\
\hline Digestive system diseases (520-579) & 269 & 0.16 & 0.02 to 1.14 & 0.48 & 0.17 to 1.35 \\
\hline Renal diseases (580-599) & 116 & 0 & & 0.95 & 0.28 to 3.28 \\
\hline
\end{tabular}

Workers in private service industry (including commerce) were considered as reference category.

CNS, central nervous system; COPD, chronic obstructive pulmonary disease; ICD-9, International Classification of Diseases, Ninth Revision.

Occupational exposure analyses highlighted a higher risk of non-accidental, malignant cancer, lung cancer and respiratory disease mortality among construction workers, of kidney cancer among construction product workers, of cardiovascular, respiratory and digestive disease mortality among male agriculture workers, of larynx cancer in dock workers, and of lymphatic cancer and neurological disease mortality in men who work in transportation.

The link between industrial PM10 and cancer and cardiac disease mortality has been observed in other studies. In 2001, a systematic review ${ }^{15}$ highlighted the association between respiratory tract cancer and the lymphohaematopoietic system and residential proximity to an industrial site. A study conducted in an Italian industrial city demonstrated higher risk of pleural cancer, kidney cancer and cardiac disease in contaminated industrial areas. ${ }^{16}$ The association between pollution, cancer, cardiovascular and respiratory diseases has been observed in several studies. $^{17-19}$

We found also a positive association between traffic $\mathrm{NO}_{x}$ and high mortality risk of all malignant cancers and neurological diseases. There is evidence that associates mortality with longterm exposure to the traffic pollutants such as $\mathrm{NO}_{\mathrm{x}}$ or particles related specifically to vehicle emissions. ${ }^{20}{ }^{21}$ In recent years, evidence has been slowly accumulating, suggesting that traffic-related air pollution may negatively affect the central nervous system and contribute to central nervous system diseases. ${ }^{22-24}$

The increased risk of lung cancer and neurological disease mortality that we observed among inhabitants within $500 \mathrm{~m}$ of the harbour could suggest an effect due to pollution caused by ship fuel and from possible past exposure to asbestos among residents near the port. In the scientific literature, the effect of diesel engine on lung cancer mortality is well documented. ${ }^{25} 26$

Higher risk of mesothelioma mortality was already known in the Civitavecchia area, with a standardised incidence rate in 2001-2013 of $4.4 \times 100000$ residents. ${ }^{27}$ Exposure to asbestos also may partly explain the excess of lung cancer near the harbour in this study, as well as the association between exposure to industrial PM10 and excess of mesothelioma mortality.

We used modelled PM10 concentrations as exposure measure of industrial pollutants on the assumption that the pollution from chimneys does not spread uniformly around the site but depends on emissions, prevailing winds and the orography of the area. We used the shape of the concentrations on the ground to rank subjects as more or less exposed, and this shape is of greater importance than are the exact absolute values. A limitation of our exposure assessment is related to the lack of a validation study with in situ measurements. Nonetheless, SPRAY is a consolidated model that has been validated using a 'conventional' validation framework $^{28}$ and its performances and efficiency have been evaluated and validated in multiple real conditions with different orography, domain size and meteorological conditions. ${ }^{29-31}$

The concentration-response curves of non-accidental, cancer and cardiac disease mortality related to industrial PM10 are consistent with a linear effect up to almost $4.5 \mu \mathrm{g} / \mathrm{m}^{3}$ exposure levels, with saturation of the effect for higher values. The association is significant even at very low exposure levels, suggesting the need to reduce the industrial components as much as possible in order to minimise the health effects.

Our study confirms knowledge already existing in the literature about the effects of occupational exposure in some sectors. A study on cement workers ${ }^{32}$ found higher lung and respiratory cancer mortality not explained by the confounding effect of smoking alone. Another study on US construction workers ${ }^{33}$ underlined significant excess mortality from all cancers, lung cancer and chronic obstructive pulmonary disease. In a case-controlled study in Montreal ${ }^{34}$ it was found that compared with other blue-collar workers, there was a slight increased risk of lung cancer in subjects who had ever been a construction worker. Several studies have already found an increased risk for respiratory diseases among workers in the agricultural sector. ${ }^{35}{ }^{36}$ An 
Australian study in 2011 on male farmers and farm managers ${ }^{37}$ underlined higher rates of all-cause mortality, neoplasms and circulatory diseases. In a study on Spanish workers, ${ }^{38}$ the prevalence of high cardiovascular risk was greater in workers from the agriculture sector than in those from industry and service sectors. The ARCAGE (Alcohol Related Cancers and Genetic Susceptibility in Europe) study has investigated the association between occupational history and upper aerodigestive tract cancer risk, including larynx cancer, and found higher risks among dock workers. ${ }^{39}$

Our study also highlighted higher risk for lymphatic and haematopoietic tissue and neurological mortality among male transportation workers. The relationship between traffic and neurological diseases has been documented previously. The literature also documents the relationship between traffic and haematopoietic disorder. In 2012, an Italian study concluded that prolonged occupational exposure to low doses of traffic pollutants could alter some lines of the haematopoietic system in exposed workers. ${ }^{40}$

The strength of this work is the population-based cohort (71362 residents) and the longitudinal study design adopted. We applied the residential cohort approach that implied the enrolment of the entire people resident in the study area. No sampling procedures were adopted, and we had no way to increase the statistical power. Therefore, the effect estimates tended to be less precise for some of the outcomes investigated and the relative 95\% CI indicated their statistical uncertainty. Results were adjusted for several confounders: age, SEP and variables related to the environmental and occupational context that might otherwise have confounded our results. However, no data were available on the personal habits of the subjects that could have had a role in the diseases investigated, especially cigarette smoking, but also alcohol use, physical activity and obesity. The lack of this information may have biased the results because of confounding not controlled in the analysis. It should be noted, however, that many personal habits are associated with SEP. It is therefore reasonable to assume that the analysis that adjusted for SEP (and occupation) also took into account other individual variables, including smoking.

We have to consider a few additional critical aspects. The dispersion model for industrial sources was estimated using emissions from 1988 because the only past data available were for that year; we could not consider temporal variations in emissions. However, although we do know the absolute emissions of the past, the relative spatial gradients of concentrations in the area are likely to be the same across various periods of time due to likely constant meteorological conditions in various decades. The study considered the air matrix very carefully, but water and/or soil pollution that via food could possibly have had negative health effects was not ruled out.

In conclusion, we found associations between industrial PM10 concentrations, $\mathrm{NO}$ from urban traffic, and proximity to harbour and cancer mortality, neurological and cardiac diseases when SEP and occupational exposures were taken into account. Past environmental and occupational exposures are responsible for the negative effects observed.

Acknowledgements We thank Alessandro Marinaccio and Stafania Massari from Department of Occupational and Environmental Medicine, Epidemiology and Hygiene, Italian Workers' Compensation Authority (INAIL), Rome, Italy, for their contribution to this work.

Contributors $L B, C a A$ and $F F$ conceived the idea of the study, together with MD, and were responsible for study design and statistical protocol. SB, RS and ChA were responsible for the exposure assessment procedures. LB was responsible for the data analysis, tables and graphs. All Authors contributed to the interpretation of the results and approved the final manuscript.

Funding The authors have not declared a specific grant for this research from any funding agency in the public, commercial or not-for-profit sectors.

Competing interests None declared.

Provenance and peer review Not commissioned; externally peer reviewed.

Open access This is an open access article distributed in accordance with the Creative Commons Attribution Non Commercial (CC BY-NC 4.0) license, which permits others to distribute, remix, adapt, build upon this work non-commercially, and license their derivative works on different terms, provided the original work is properly cited, appropriate credit is given, any changes made indicated, and the use is non-commercial. See: http://creativecommons.org/licenses/by-nc/4.0/.

\section{REFERENCES}

1 Bonassi S, Ceppi M, Puntoni R, et al. Mortality studies of dockyard workers (longshoremen) in Italy. Am J Ind Med 1985;7:219-27.

2 Rapiti E, Turi E, Forastiere F, et al. A mortality cohort study of seamen in Italy. Am J Ind Med 1992;21:863-72.

3 Forastiere F, Pupp N, Magliola E, et al. Respiratory cancer mortality among workers employed in thermoelectric power plants. Scand J Work Environ Health 1989;15:383-6.

4 Forastiére F, Corbo GM, Michelozzi P, et al. Effects of environment and passive smoking on the respiratory health of children. Int J Epidemiol 1992;21:66-73.

5 Forastiere F, Corbo GM, Pistelli R, et al. Bronchial responsiveness in children living in areas with different air pollution levels. Arch Environ Health 1994;49:111-8.

6 Fano V, Michelozzi P, Ancona C, et al. Occupational and environmental exposures and lung cancer in an industrialised area in Italy. Occup Environ Med 2004;61:757-63.

7 Fano V, Forastiere F, Papini P, et al. Mortality and hospital admissions in the industrial area of Civitavecchia, 1997-2004. Epidemiol Prev 2006;30(4-5):221-6.

8 Ancona C, Badaloni C, Mataloni F, et al. Mortality and morbidity in a population exposed to multiple sources of air pollution: A retrospective cohort study using air dispersion models. Environ Res 2015;137:467-74.

9 Ranzi A, Fano V, Erspamer L, et al. Mortality and morbidity among people living close to incinerators: a cohort study based on dispersion modeling for exposure assessment Environ Health 2011;10:22.

10 Barregard L, Holmberg E, Sallsten G. Leukaemia incidence in people living close to an oil refinery. Environ Res 2009;109:985-90.

11 Ancona C, Mataloni F, Badaloni C, et al. Population cohort study in areas at high environmental pressure: the ERAS Lazio study. Epidemiol Prev 2014;38:158-61.

12 Barbera C, Petrucci G, Pomponi GGR. Censimento Delle Sorgenti Di Emissione E Calcolo Degli Inquinanti Emessi in Atmosfera Nel Comprensorio Di Civitavecchia Tarquinia E Santa Marinella Durante L'anno 1988. 1988

13 Cesaroni G, Agabiti N, Rosati R, et al. [An index of socioeconomic position based on 2001 Census, Rome]. Epidemiol Prev 2006;30:352-7.

14 Madouasse A, Browne WJ, Huxley JN, et al. A semi-parametric model for lactation curves: development and application. Prev Vet Med 2012;105(1-2):38-48.

15 Benedetti $\mathrm{M}$, lavarone I, Comba $\mathrm{P}$, et al. Cancer risk associated with residentia proximity to industrial sites: a review. Arch Environ Health 2001;56:342-9.

16 Mataloni F, Stafoggia M, Alessandrini E, et al. Studio di coorte sulla mortalità e morbosità nell' area di Taranto $A$ cohort study on mortality and morbidity in the area of Taranto, Southern Italy. Epidemiol Prev 2012;36:237-52.

17 Hamra GB, Guha N, Cohen A, et al. Outdoor particulate matter exposure and lung cancer: a systematic review and meta-analysis. Environ Health Perspect 2014;122:906-11.

18 Pope CA, Burnett RT, Thurston GD, et al. Cardiovascular mortality and longterm exposure to particulate air pollution: epidemiological evidence of general pathophysiological pathways of disease. Circulation 2004;109:71-7.

19 Pelucchi C, Negri E, Gallus S, et al. Long-term particulate matter exposure and mortality: a review of European epidemiological studies. BMC Public Health 2009:9:453.

20 Beelen R, Stafoggia M, Raaschou-Nielsen 0, et al. Long-term exposure to air pollution and cardiovascular mortality: an analysis of 22 European cohorts. Epidemiology 2014;25:368-78

21 Cesaroni G, Badaloni C, Gariazzo C, et al. Long-term exposure to urban air pollution and mortality in a cohort of more than a million adults in Rome. Environ Health Perspect 2013:121:324-31.

22 Grandjean P, Landrigan PJ. Neurobehavioural effects of developmental toxicity. Lancet Neurol 2014;13:330-8.

23 Kim YD, Lantz-McPeak SM, Ali SF, et al. Effects of ultrafine diesel exhaust particles on oxidative stress generation and dopamine metabolism in PC-12 cells. Environ Toxicol Pharmacol 2014;37:954-9.

24 Levesque S, Surace MJ, McDonald J, et al. Air pollution \& the brain: Subchronic diesel exhaust exposure causes neuroinflammation and elevates early markers of neurodegenerative disease. J Neuroinflammation 2011;8:105. 
25 Vermeulen R, Silverman DT, Garshick E, et al. Exposure-response estimates for diesel engine exhaust and lung cancer mortality based on data from three occupational cohorts. Env Heal Perspect 2014;122:172-7.

26 Moolgavkar SH, Chang ET, Luebeck G, et al. Diesel engine exhaust and lung cancer mortality: time-related factors in exposure and risk. Risk Anal 2015;35:663-75.

27 Romeo E, Ancona L, Bauleo L, et al. Incidenza di mesotelioma nel Lazio Rapporto sulle attività del COR Lazio Tumori professionali, 2014. 2014 http://deplazio.net/it/tumoriprofessionali.

28 Olesen HR. Toward the Establishment of a Common Framework for Model Evaluation. In: Air Pollution Modeling and Its Application XI, 1996:519-28.

29 Anfossi D, Tinarelli G, Trini Castelli S, et al. A new Lagrangian particle model for the simulation of dense gas dispersion. Atmos Environ 2010;44:753-62.

30 Brusasca G, Tinarelli G, Anfossi D. Comparison between the results of a Monte Carlo atmospheric diffusion model and tracer experiments. Atmos Environ 1989:23:1263-80.

31 Brusasca G, Tinarelli G, Anfossi D. Particle model simulation of diffusion in low wind speed stable conditions. Atmos Environ Part a Gen Top 1992;26:707-23.

32 Rachiotis G, Drivas S, Kostikas K, et al. Respiratory tract mortality in cement workers: a proportionate mortality study. BMC Pulm Med 2012;12:30.
33 Ringen K, Dement J, Welch L, et al. Mortality of older construction and craft workers employed at department of energy (DOE) nuclear sites: follow-up through 2011. Am J Ind Med 2015;58:152-67.

34 Lacourt A, Pintos J, Lavoué J, et al. Lung cancer risk among workers in the construction industry: results from two case-control studies in Montreal. BMC Public Health 2015;15:941.

35 Linaker C, Smedley J. Respiratory illness in agricultural workers. Occup Med 2002;52:451-9.

36 Ye M, Beach J, Martin JW, et al. Occupational pesticide exposures and respiratory health. Int J Environ Res Public Health 2013;10:6442-71.

37 Fragar L, Depczynski J, Lower T. Mortality patterns of Australian male farmers and farm managers. Aust J Rural Health 2011;19:179-84.

38 Sánchez Chaparro MA, Calvo Bonacho E, González Quintela A, et al. High cardiovascular risk in Spanish workers. Nutr Metab Cardiovasc Dis 2011;21:231-6.

39 Richiardi L, Corbin M, Marron M, et al. Occupation and risk of upper aerodigestive tract cancer: the ARCAGE study. Int J Cancer 2012;130:2397-406.

40 Sancini A, Tomei F, Gioffrè PA, et al. Occupational exposure to traffic pollutants and peripheral blood counts. Ann Ig 2012;24:325-44. 